\title{
A Reserva legal florestal diante do novo direito de propriedade: análise da Constitucionalidade do projeto de lei № 143/ 2009 do Estado do Paraná
}

\author{
Ana Cláudia Duarte Pinheiro ${ }^{1}$ \\ Luana Madureira dos Anjos ${ }^{2}$
}

\begin{abstract}
Resumo
0 presente trabalho tem por fim o estudo da Reserva Legal Florestal diante do novo direito de propriedade consagrado pela Constituição Federal de 1988, vez que há, no Estado do Paraná, Projeto de Lei Estadual no 143/2009 que pretende compensar financeiramente o proprietário rural paranaense que cumprir com a cota de Reserva Legal em seu imóvel. Assim, analisou-se a nova estrutura do direito de propriedade consagrado pela Constituição Federal de 1988, tendo-se em vista a sua função socioambiental, ali preceituada como inerente a tal direito, fundamentando a existência de certas limitações administrativas de caráter ambiental. Dessa forma provou-se que a Reserva Legal é limitação administrativa ao direito de propriedade fundamentada em sua função socioambiental e, por assim ser, é gratuita, configurando-se em obrigação imposta ao proprietário rural de maneira genérica, simplesmente por esse figurar como tal. Com isso, conclui-se pela inconstitucionalidade do Projeto de Lei no 143/2009, tendo em vista sua incompatibilidade com os dispositivos constitucionais que prevêem a existência da função socioambiental da propriedade como um dever imposto ao proprietário, a qual legitima o instituto da Reserva Legal como limitação administrativa ao direito de propriedade, devendo ser, portanto, gratuita.
\end{abstract}

Palavras-Chave: Direito de Propriedade; Função Socioambiental da Propriedade; Limitação Administrativa; Reserva Legal Florestal; Projeto de Lei № 143/2009.

\section{Introdução}

Com o advento da Constituição Federal de 1988, o direito de propriedade sofreu intensa transformação em sua estrutura, na medida em que foi estabelecida a necessidade de se atender a sua função social que, por conseguinte, se desdobra em função ambiental. Dessa forma, queda clara a impossibilidade de se entender o direito de propriedade como absoluto, tal como era compreendido no passado.

\footnotetext{
${ }^{1}$ Mestre em Direito Negocial pela UEL, professora de Direito Ambiental e Urbanístico para o Curso de Direito da UEL - professora orientadora do Trabalho de Conclusão de Curso apresentado.

${ }^{2}$ Acadêmica do 5o ano do Curso de Direito da Universidade Estadual de Londrina - UEL - PR.
} 
Tendo isso em vista, propõe-se o estudo da Reserva Legal Florestal frente à propriedade, pela importância que representa tal instituto para a preservação do meio ambiente e na medida em que tem sido tema alvo de muitas discussões, especialmente no Estado do Paraná, em que existe, inclusive, um Projeto de Lei (no 143/2009) que visa instituir o pagamento ao proprietário de imóvel que cumprir a cota de Reserva Legal em sua respectiva propriedade.

Nesse sentido, este trabalho buscará um estudo mais aprofundado do instituto da Reserva Legal, sem se olvidar da análise do direito de propriedade e de sua função socioambiental, como também das limitações impostas ao proprietário em virtude dessa. Assim, pretende-se, relacionando tais institutos, discutir a constitucionalidade de referido Projeto de Lei.

\section{0 direito de propriedade na Constituição Federal de 1988}

Na Constituição Federal de 1988 são vários os artigos que reportam ao direito à propriedade, tais quais: artigos 5ㅇ, incisos XXII a XXX, 170, incisos II e III, 176 a 178, 182 a 186,191 e 222.

Entretanto, não obstante a relevância de cada um desses artigos, em um primeiro momento é de suma importância, para a compreensão do direito de propriedade na atual Constituição, a percepção, de acordo com os incisos XXII e XXIII de seu artigo $5^{0}{ }^{3}$, de que 0 direito de propriedade é garantido quando e desde que essa cumpra a sua função social, como ensina André Ramos Tavares (2007, p. 603), ao explicar que: "embora assegurada individualmente, a propriedade deverá atender a sua função social".

Dessa forma, ao arrolar tais preceitos entre os direitos e garantias fundamentais, a Carta Magna de 1988 os torna insuscetíveis de serem alterados ou suprimidos (artigo 60, parágrafo 4을 inciso IV) e proporciona-os imediatidade, já que 0 parágrafo 10 do artigo 5은 determina que as normas definidoras dos direitos e garantias fundamentais terão aplicação imediata, como entende José Afonso da Silva (2005, p. 282) ao explicar que "a norma que

\footnotetext{
${ }^{3}$ Art. 5 ㅇ Todos são iguais perante a lei, sem distinção de qualquer natureza, garantindo-se aos brasileiros e aos estrangeiros residentes no País a inviolabilidade do direito à vida, à liberdade, à igualdade, à segurança e à propriedade, nos termos seguintes:

XXII - é garantido o direito de propriedade;

XXIII - a propriedade atenderá a sua função social;
} 
contém o princípio da função social da propriedade incide imediatamente, é de aplicabilidade imediata, como o são todos os princípios constitucionais."

Ainda, importante perceber que o direito à propriedade e sua função social também encontram- se entre os princípios gerais da atividade econômica (artigo 170, incisos II e III ${ }^{4}$ ), a qual, por sua vez, visa, como descrito no caput do artigo 170, "assegurar a todos existência digna, conforme os ditames da justiça social", o que significa que a propriedade está, ainda, vinculada a esse princípio, de forma que deixa de ser entendida puramente como direito individual.

É evidente, pois, a importância da inovação trazida pela presente Constituição em matéria de propriedade, visto que, ao mesmo tempo em que garante o direito à propriedade como um direito individual, já fixa, em parte, os limites de seu conteúdo (GRYSARD FILHO, 2007, p. 247).

Assim é que 0 direito à propriedade, atualmente, não pode mais ser entendido apenas como um direito garantido constitucionalmente, de caráter puramente individual, e que tem seu conteúdo limitado somente por leis, como se dava nas constituições anteriores. É sim garantido como direito individual pela Constituição Federal de 1988, mas, simultaneamente, delimitado em seu exercício e conteúdo no próprio texto constitucional, que serve de norte interpretativo das disposições infraconstitucionais, devendo referido direito ser exercido também em benefício da coletividade, atendendo ao princípio da função social da propriedade, o qual, como visto, tem aplicabilidade imediata, de modo a assegurar a todos uma existência digna, consoante os ditames da justiça social.

Queda claro, pois, que a nova Constituição brasileira deixa de tratar do direito à propriedade como absoluto, perdendo o direito brasileiro seu caráter patrimonialista, de forma que protege a propriedade enquanto essa sirva como meio de realização de valores constitucionais, produzindo ganhos sociais, econômicos e ambientais capazes de estender-se a futuras gerações.

\footnotetext{
${ }^{4}$ Art. 170. A ordem econômica, fundada na valorização do trabalho humano e na livre iniciativa, tem por fim assegurar a todos existência digna, conforme os ditames da justiça social, observados os seguintes princípios: II - propriedade privada;

III - função social da propriedade;
} 


\section{A função sócio ambiental da propriedade rural}

Função "é o dever que legitima o poder", como conclui Patrícia Faga Iglecias Lemos (2008, p. 75), após elucidar seu conceito de acordo com Herman Benjamin.

Observa-se que o exercício dos direitos do proprietário frente à propriedade flexibilizam-se de acordo com a orientação política- estrutural do Estado, conforme o regime constitucional assumido em relação à propriedade.

Assim, para José Afonso da Silva (2003, p. 282-283) o direito de propriedade no Brasil não pode mais ser compreendido como individual, vez que a Constituição, ao estabelecer o princípio da função social da propriedade, inclusive como princípio geral informador da ordem econômica (artigo 170, inciso III) e ao mesmo tempo não impedir a existência do instituto da propriedade, transforma a natureza dessa, isto é, modifica a própria configuração do direito de propriedade. Por esse motivo, o referido autor acredita que a propriedade deveria ter sido prevista apenas como instituição do Direito Econômico.

André Ramos Tavares, por sua vez, crê que o fato de a propriedade não poder mais ser compreendida de modo puramente individualista não significa que deverá ser entendida apenas como um objeto de conformação dos fins sociais, ou seja, não se pode compreender a propriedade como se essa correspondesse simplesmente a uma função, ignorando-se 0 direito. Dessa forma, afirma o citado autor (2007, p. 613) que a propriedade é garantida constitucionalmente de maneira genérica como um direito individual, sendo, entretanto, seu conteúdo já delimitado pela própria Constituição, ao estabelecer que essa deverá cumprir sua função social, garantindo existência digna nos ditames da justiça social.

Em sendo assim, tendo em vista o texto da Constituição Federal de 1988, é forçoso o entendimento de que a propriedade não é a função social, mas a possui, posto que não é apenas tratada no Título VII (Da Ordem Econômica e Financeira), Capítulo I (Dos Princípios Gerais da Atividade Econômica), como gostaria José Afondo da Silva (2003, p. 283).

Observa-se que a propriedade possui a função social segundo 0 ordenamento jurídico brasileiro, tendo em vista que 0 artigo 50 da Constituição, o qual determina 0 direito de propriedade, bem como 0 atendimento de sua função social nos seus incisos XXII e XXIII, encontra-se presente no capítulo referente aos direitos individuais e coletivos. Isso significa que a Carta Magna de 1988 estabelece tal direito como individual, ainda que não absoluto, vez que ao defini-lo já estabelece em seguida que deverá cumprir a sua função social. 
Mais ainda, torna-se possível afirmar que, de acordo com 0 artigo $225^{5}$ da Constituição Federal, a propriedade, da mesma forma que possui a função social, tem também função ambiental, de modo que quando o que está em questão é a propriedade do bem ambiental, está-se diante da função socioambiental da propriedade (LEM OS, 2008, p. 80-81).

Inova, pois, a Constituição Federal de 1988, ao prever no seu artigo 225 uma nova espécie de bem, isto é, uma terceira espécie, tendo em vista que o bem ali disposto não é público nem privado, mas de uso comum do povo, como ensina Celso Antonio Pacheco Fiorillo (2009, p. 14), explicando que a compreensão do disposto nesse artigo implica quatro concepções fundamentais para o direito ambiental, dentre elas a "de que a Carta Maior determina tanto ao Poder Público como à coletividade 0 dever de defender 0 bem ambiental, assim como o dever de preservá-lo".

Dessa forma, observa-se que a Constituição Federal de 1988 não apenas estabeleceu a existência de um bem ambiental, bem de uso comum do povo, mas determinou, tendo em vista justamente o fato de assim dever ser compreendido - por terem todos o direito ao meio ambiente ecologicamente equilibrado, necessário à sadia qualidade de vida -, que é dever da coletividade, bem como do Poder Público, defender e preservá-lo, já que tais incumbências dizem respeito tanto à presente como às futuras gerações.

Assim, é evidente, pelos motivos acima explicitados, que todos, isto é brasileiros e estrangeiros residentes no país de acordo com 0 artigo 5o da Carta Magna, e inclusive 0 Poder Público, possuem o dever de preservar e defender o bem ambiental, evidenciando-se aqui a presença da função socioambiental da propriedade.

Ainda, é de suma importância a observância do artigo $186^{6}$ da Constituição Federal, o qual estabelece como um dos requisitos que devem ser obedecidos simultaneamente para

\footnotetext{
${ }^{5}$ Art. 225. Todos têm direito ao meio ambiente ecologicamente equilibrado, bem de uso comum do povo e essencial à sadia qualidade de vida, impondo-se ao Poder Público e à coletividade o dever de defendê-lo e preservá- lo para as presentes e futuras gerações.

${ }^{6}$ Art. 186. A função social é cumprida quando a propriedade rural atende, simultaneamente, segundo critérios e graus de exigência estabelecidos em lei, aos seguintes requisitos: I - aproveitamento racional e adequado;

II - utilização adequada dos recursos naturais disponíveis e preservação do meio ambiente;

III - observância das disposições que regulam as relações de trabalho;

IV - exploração que favoreça o bem-estar dos proprietários e dos trabalhadores.
} 
o cumprimento da função social da propriedade rural a "utilização adequada dos recursos naturais disponíveis e preservação do meio ambiente" (inciso II).

Verifica-se, portanto, uma clara consonância com o artigo 225 da Carta Magna, ou seja, com a tutela ambiental. Isso significa que tal dispositivo consigna em seu conteúdo a função ambiental como um dos componentes da função social da propriedade rural, não podendo essa ser olvidada, já que as condições devem ser atendidas simultaneamente, estando, portanto, previsto no texto constitucional a função socioambiental da propriedade rural.

Isso posto, claro está, pelos motivos explicados, que a propriedade no Brasil não deixou de ser direito para tornar-se função. Entretanto, o direito à propriedade alterou-se no conteúdo diante do advento dos direitos sociais pela Constituição Federal de 1988, a qual previu, expressamente, que a propriedade deverá cumprir sua função social, ou seja, que "também a propriedade é alcançada pela concepção social do Direito" (TAVARES, 2007, p. 613).

Assim, transforma a Constituição vigente o conteúdo do direito de propriedade, ao delimitar ela própria parte desse, impondo o atendimento da função social da propriedade. Mas não é só isso, já que também estabelece como será cumprida tal função, sendo que no que tange à propriedade rural é o artigo 186 que se encarrega do assunto, arrolando, dentre as condições necessárias para seu cumprimento, uma correspondente ao atendimento da função ambiental.

\section{Limitações administrativas}

De acordo com Hely Lopes M eirelles (2007, p. 600), a limitação administrativa é, conjuntamente com a desapropriação, servidão administrativa, requisição e ocupação temporária, uma das formas de intervenção na propriedade particular, a qual, por sua vez, pode acontecer em razão de necessidade, utilidade pública ou interesse social.

Assim é que a limitação administrativa - que não se confunde com a civil, por figurar como restrição de ordem pública, de modo que protege genericamente a coletividade, sendo, portanto, regida pelo Direito Administrativo e não pelo Privado, que protege especificamente os vizinhos (artigo 1.277 e ss. do Código Civil) - pode ser definida, segundo Meirelles (2007, p. 632), como: "toda a imposição geral, gratuita, unilateral e de ordem 
pública condicionadora do exercício de direitos ou de atividades particulares às exigências do bem-estar social."

Dessa forma, as limitações administrativas, de acordo com o autor supracitado, são imposições gerais, isto é, "dirigidas a propriedades indeterminadas, mas determináveis no momento de sua aplicação" (M EIRELLES, 2007, p. 633); são gratuitas, pois não implicam em indenização, diferentemente da servidão e da desapropriação, as quais ocorrem em situações determinadas e não gerais, quando houver conflito com interesse público; são unilaterais, uma vez que são impostas por lei, independentemente do consentimento do proprietário; e são de ordem pública, donde decorre sua imperatividade, no sentido de que deverão ser cumpridas. Ainda, as tais imposições poderão importar em obrigações de fazer, de não fazer ou de permitir que se faça.

Salienta-se que as limitações administrativas visam o bem estar social, isto é, o bem comum, caracterizando-se como o objetivo da "justiça social" a que se refere o artigo 170, da Constituição Federal, de modo que encontram-se justificadas em seu inciso III, ou seja, na função social da propriedade, também estabelecida no artigo 5ํ, inciso XXIII da Carta Magna.

Interessante observar, conforme ensina Di Pietro (2002, p. 117-118), que o exercício da atividade de limitação ao domínio privado cabe à Administração Pública, "por meio do poder de polícia fundado na supremacia do interesse público sobre o particular", e que as limitações administrativas ao direito de propriedade a afetam no seu caráter absoluto que, como visto, não pode mais ser assim entendido, de modo que ao proprietário não é autorizado o uso, gozo e disposição - que são poderes do proprietário sobre sua propriedade de acordo com o artigo $1.228^{7}$ do Código Civil - do bem como melhor the aprouver, tendo em vista exatamente a superveniência do interesse público sobre 0 particular.

Ainda, faz-se necessário ressaltar que a limitação administrativa é imposta genericamente, não constituindo "restrição especial nem despojamento da propriedade, caso em que, se o interesse público exigir, impõe-se a servidão administrativa ou a desapropriação conforme a amplitude do impedimento imposto ao proprietário"

\footnotetext{
${ }^{7}$ Art. 1.228. 0 proprietário tem a faculdade de usar, gozar e dispor da coisa, e o direito de reavê-lo do poder de quem quer que injustamente a possua ou detenha.
} 
(MEIRELLES, 2007, p. 640, grifo do autor), e que só acontecem em situações específicas, dando direito à indenização, na medida em que gerem prejuízos a determinado particular, por situação também determinada.

Por isso, vez que a limitação administrativa está imposta a toda uma categoria de bens, recaindo como condição inerente ao exercício de direitos sobre esses, não implicando nunca diminuição ou perda dos direitos relacionados à propriedade, mas o condicionamento do exercício conforme o interesse comum, não é razoável o entendimento de que produzam prejuízos ao proprietário (CARVALHO, 2008, p. 969), pois, se chegam a produzi-los, será de caráter geral. Não há que se falar, portanto, em nenhuma hipótese, em indenização por limitação administrativa. Se houver indenização é porque se trata de outra forma de intervenção na propriedade particular, que não a em questão.

Em última análise, portanto, pode-se afirmar que o prejuízo por ventura gerado pela limitação administrativa será para todos (proprietários de determinada categoria de bens) e em favor de todos (do bem comum, interesse coletivo). Se assim não for, não há que se falar em limitação administrativa, podendo-se, então, existir direito à indenização, exatamente por só ser legítimo, de acordo com M eirelles (2007, p. 640), “o ônus suportado por todos, em favor de todos", sendo esse, ainda conforme tal autor, o significado do princípio da solidariedade social.

\section{A limitação administrativa e a função socioambiental}

Como visto, a função social é aspecto constitutivo do direito de propriedade, elemento integrante desse, vez que o ordenamento jurídico só protege o bem que a cumpra, como ensina Raquel M elo Urbano de Carvalho (2008, p. 953). Tem, pois, a função em tela, manifestação na própria estrutura do direito de propriedade, delimitando seu conteúdo, na medida em que condiciona tal direito a seu cumprimento.

As limitações administrativas, a seu turno, são imposições unilaterais, gerais, gratuitas e de ordem pública, com vistas a condicionar o exercício dos direitos relacionados à propriedade para o bem-estar social. Atingem, portanto, o exercício do direito de propriedade, isto é, as faculdades de uso, gozo e disposição que possui o proprietário. Temse claro, então, que a esse, isto é, ao proprietário, é que se dirige a limitação ora estudada e não ao direito de propriedade, o qual é atingido pela função social. 
Em sendo assim, vez que as limitações em tela são impostas em virtude do interesse público, sendo concernentes ao Direito Administrativo, é que, segundo Lemos (2008, p. 42), "tais restrições podem apresentar caráter ambiental." Nesse passo, afirma-se que a função socioambiental da propriedade, por ser elemento que define o próprio conteúdo de direito de propriedade, legitima tais limitações administrativas de caráter ambiental, as quais devem, necessariamente, ter uma conformação social (LEM OS, 2008, p. 81).

Dessa forma, observa-se que a função socioambiental da propriedade serve de base para as limitações administrativas de caráter ambiental, isto é, as limitações que condicionam o exercício do direito de propriedade com vistas a proteger, preservar e manter o meio ambiente ecologicamente equilibrado, a que todos têm direito, bem de uso comum do povo e essencial à sadia qualidade de vida, consoante 0 artigo 225 da Constituição Federal.

Assim é que o direito de propriedade, por não mais ser absoluto, encontra-se condicionado pela função social, ou melhor, socioambiental, tendo em vista possuir a propriedade também função ambiental de acordo com o já citado artigo 225 da Constituição Federal, que fundamenta as limitações administrativas de tal caráter, determinadas por lei, como é o caso do Código Florestal (lei 4771/1965), o qual institui a área de Reserva Legal Florestal.

\section{Reserva Legal Florestal}

A Reserva Legal Florestal ou Reserva Legal, como preferem alguns autores, figura, juntamente com a área de preservação permanente, como valioso espaço protegido pelo Código Florestal de 1965 (Lei Federal 4.771), o qual, segundo Paulo Bessa Antunes (2005, p. 475), deve ser entendido como lei geral, de acordo com o artigo 24, inciso VI e parágrafo 10 8 e artigo 23, inciso $\mathrm{VII}^{9}$ da Constituição Federal de 1988, estabelecendo os princípios gerais que devem ser observados pelos demais Estados-M embros.

\footnotetext{
${ }^{8}$ Art. 24. Compete à União, aos Estados e ao Distrito Federal legislar concorrentemente sobre:

$\mathrm{VI}$ - florestas, caça, pesca, fauna, conservação da natureza, defesa do solo e dos recursos naturais, proteção do meio ambiente e controle da poluição;

$\S 1$ - No âmbito da legislação concorrente, a competência da União limitar-se-á a estabelecer normas gerais.

9 Art. 23. É competência comum da União, dos Estados, do Distrito Federal e dos Municípios:

$\mathrm{VII}$ - preservar as florestas, a fauna e a flora;
} 
0 artigo $1^{10}{ }^{10}$ do referido Código estabelece que as florestas e demais vegetações determinadas permanentes são bens comuns do povo, devendo estar limitadas quando do exercício dos direitos de propriedade, tanto por normas derivadas da legislação genericamente, como pelas especificadas nessa própria Lei Federal, sendo que em seu parágrafo 2을 inciso $1 \mathrm{II}^{11}$, trazido pela Medida Provisória 2.166-67/2001, define a Reserva Legal.

Assim, percebe-se que a Reserva Legal, bem como as florestas e as demais formas de vegetação permanente, "decorre de normas legais que limitam o direito de propriedade, (...) previstas também no Código Florestal", como ensina Machado (2005, P. 739), ou, nas palavras de Paulo Bessa Antunes (2005, p. 510): "ela nada mais é que a aplicação concreta

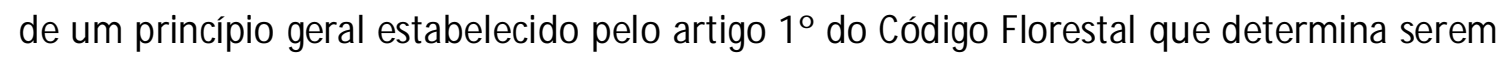
as florestas um interesse comum de todos os habitantes do país."

A Reserva Legal encontra-se, como ensina Machado (2005, p. 740), de acordo com o artigo 225, parágrafo $1^{\circ}$, inciso $1 I^{12}$ da Constituição Federal, figurando como espaço territorial especialmente protegido definido pelo Poder Público em todas as unidades da Federação, podendo ser alterado ou suprimido apenas por meio de lei, com vistas a garantir 0 meio ambiente ecologicamente equilibrado, considerado bem de interesse comum do povo e imprescindível para uma vida saudável. Tem-se em vista, pois, a presente e futuras gerações, o respeito à vontade e ao direito de toda a sociedade e de cada indivíduo de ter uma sadia qualidade de vida, sendo, portanto, de interesse inclusive do próprio proprietário.

Observa-se, ainda, que a Reserva Legal encontra-se também amparada pelo artigo 170, incisos II, III e VI ${ }^{13}$. Isso porque tais incisos dispõem que a ordem econômica, a qual tem por fim assegurar uma existência digna, de acordo com a justiça social, deve atender aos

${ }^{10}$ Art. $1^{\circ}$ As florestas existentes no território nacional e as demais formas de vegetação, reconhecidas de utilidade às terras que revestem, são bens de interesse comum a to dos os habitantes do País, exercendo-se os direitos de propriedade, com as limitações que a legislação em geral e especialmente esta Lei estabelecem.

11 §20 Para os efeitos deste Código, entende-se por:

III - Reserva Legal: área localizada no interior de uma propriedade ou posse rural, excetuada a de preservação permanente, necessária ao uso sustentável dos recursos naturais, à conservação e reabilitação dos processos ecológicos, à conservação da biodiversidade e ao abrigo e proteção de fauna e flora nativas

$12 \S 10$ - Para assegurar a efetividade desse direito, incumbe ao Poder Público:

III - definir, em todas as unidades da Federação, espaços territoriais e seus componentes a serem especialmente protegidos, sendo a alteração e a supressão permitidas somente através de lei, vedada qualquer utilização que comprometa a integridade dos atributos que justifiquem sua proteção;

$13 \mathrm{VI}$ - defesa do meio ambiente, inclusive mediante tratamento diferenciado conforme 0 impacto ambiental dos produtos e serviços e de seus processos de elaboração e prestação; 
princípios da função social da propriedade e da defesa do meio ambiente, os quais "servem de suporte para a atuação intervencionista do Código Florestal e tudo aquilo que Ihe seja correlato", como ensina Bessa Antunes (2005, p. 506).

Dessa forma, por estar a Reserva Legal amparada por ambos os dispositivos referidos acima, quais sejam, os artigos 225 , parágrafo 1ㅇ, inciso III e 170, incisos II, III e VI, bem como pelo artigo 50, incisos XXII e XXIII, e 186, inciso II, todos da Constituição Federal de 1988, é que, nas palavras de M achado (2005, p. 738) "deve ser adequada à tríplice função da propriedade: econômica, social e ambiental", acrescentando renomado autor que, "usase menos a propriedade para usar-se sempre", de maneira que afirma ainda ser a existência de uma Reserva Legal Florestal "mais do que uma imposição legal, um ato de amor a si mesmo e a seus descendentes".

Ainda, é imperioso observar que o percentual de Reserva Legal varia de acordo com a região em que a propriedade encontra-se localizada, assim como com o tipo de vegetação existente, sendo que 0 artigo $16^{14}$ do Código Florestal, que também possui nova redação dada pela já mencionada Medida Provisória 2.166-67/2001, elenca em seus incisos qual deverá ser a porcentagem mínima de cobertura florestal a ser preservada a título de Reserva Legal.

Importante perceber, de acordo com Luciano José Alvarenga (2008, p. 178-179), que, interpretando-se conjuntamente o relacionado artigo 16, caput e incisos III e IV- que estabelece a manutenção a título de Reserva Legal de $20 \%$ de propriedades situadas em áreas tanto de florestas, como de vegetação nativa ou mesmo de campos gerais localizadas em qualquer região do país-, com 0 artigo $1^{\circ}$, parágrafo $2^{\circ}$, , inciso III também do Código Florestal, o qual define a Reserva Legal como "área localizada no interior de uma propriedade ou posse rural", não havendo, portanto, referência apenas ao tipo de vegetação ali existente, verifica-se que 0 alcance da Lei Federal em tela quanto às áreas que devem ser

${ }^{14}$ Art. 16. As florestas e outras formas de vegetação nativa, ressalvadas as situadas em área de preservação permanente, assim como aquelas não sujeitas ao regime de utilização limitada ou objeto de legislação específica, são suscetíveis de supressão, desde que sejam mantidas, a título de reserva legal, no mínimo: I - oitenta por cento, na propriedade rural situada em área de floresta localizada na Amazônia Legal;

II - trinta e cinco por cento, na propriedade rural situada em área de cerrado localizada na Amazônia Legal, sendo no mínimo vinte por cento na propriedade e quinze por cento na forma de compensação em outra área, desde que esteja localizada na mesma microbacia, e seja averbada nos termos do § 70 deste artigo; III - vinte por cento, na propriedade rural situada em área de floresta ou outras formas de vegetação nativa localizada nas demais regiões do País; e

IV - vinte por cento, na propriedade rural em área de campos gerais localizada em qualquer região do País. 
demarcadas, averbadas e conservadas a título de Reserva Legal não está restrito às áreas com coberturas florestais, abrangendo todos os tipos ecológico-florísticos e vegetações nativas presentes no território brasileiro, como explica Alvarenga (2008, p. 179).

Nesse liame, vez que 0 artigo 44 da Lei Federal em questão preceitua que quando a propriedade rural apresentar "área de floresta nativa, natural, primitiva ou regenerada ou outra forma de vegetação nativa" que tenha menor extensão que os percentuais dispostos no artigo 16, o proprietário terá o dever de, isolada ou conjuntamente, "recompor a reserva legal de sua propriedade" (inciso I), "conduzir a regeneração natural da reserva legal" (inciso II) e "compensar a reserva legal por outra área equivalente em importância ecológica e extensão" (inciso III), verifica-se que, ainda que desmatadas as áreas destinadas à manutenção à título de Reserva Legal, tem o proprietário o dever de recompô-las.

Nesse sentido, se o próprio Código Florestal determina que o proprietário ou possuidor deve recuperar a Reserva Legal, é óbvio que a obrigatoriedade de averbação da área independerá da existência da mata nativa conservada, evidenciando-se, dessa maneira, que, ainda que ausente essa, bem como vegetação florestal, não respeitando-se os percentuais mínimos obrigatórios de Reserva Legal, resistirá a obrigatoriedade de sua demarcação, averbação, conservação e até mesmo recuperação

Importante também notar que, de acordo com o estabelecido no parágrafo $2^{\circ}$ do artigo 16, a Reserva Legal não poderá ser suprimida, "mas sim utilizada sob regime de manejo florestal sustentável, de acordo com princípios e critérios técnicos e científicos estabelecidos no regulamento (...)". Não ocorre, com a constituição da Reserva Legal, nem a total inviabilização da propriedade rural, já que é apenas uma parte da propriedade que terá essa destinação, nem tampouco de parte dela, visto que será utilizada em regime de manejo sustentável. Sendo que, ainda, em se tratando de pequena propriedade ou posse rural familiar, o parágrafo 3o estabelece que para o cumprimento da manutenção da Reserva Legal nessa área poderão "ser computados os plantios de árvores frutíferas ornamentais ou industriais, compostos por espécies exóticas, cultivadas em sistema intercalar ou em consórcio com espécies nativas", evidenciando-se, portanto, a preocupação do Código Florestal em não onerar demasiado o pequeno proprietário rural.

Ainda, o parágrafo 40 do artigo 16 do Código Florestal determina que a localização da área de Reserva Legal dependerá de aprovação do órgão ambiental estadual competente 
ou do órgão ambiental municipal, mediante convênio, ou, ainda, de outra instituição habilitada. E o parágrafo 80 desse mesmo dispositivo, por sua vez, preceitua que a Reserva legal deverá ser averbada à margem da matrícula do imóvel, sendo que a sua destinação não poderá ser alterada em qualquer caso de transmissão ou mesmo diante de desmembramento ou retificação.

Assim é que a Reserva Legal, uma vez devidamente aprovada e averbada, com fundamento na função social da propriedade, nos termos dos parágrafos $2^{\circ}$, $4^{\circ}$ e e $8^{\circ}$ do artigo 16 da Lei Federal 4.771/1965, bem como de ter havido qualquer tipo de transmissão ou modificação, não poderá ter sua destinação desviada, acompanhando a propriedade, de modo a restringir o exercício dos direitos do proprietário sobre sua propriedade rural, pelo simples fato desse figurar com tal.

\section{A Reserva Legal como limitação administrativa fundamentada na função socioambiental da propriedade: o não cabimento de indenização}

Inicialmente, cabe demonstrar que a Reserva Legal Florestal corresponde a uma forma de limitação administrativa de caráter ambiental. Assim, segundo a característica da generalidade, as limitações administrativas são restrições direcionadas a todos os proprietários que se encontrem em determinadas circunstâncias, isto é, aos proprietários de uma certa categoria de bens.

Sendo assim, a Reserva Legal apresenta tal qualidade, na medida em que é imposta a todo proprietário de imóvel rural, ainda que não possua espaços densamente florestados ou mesmo vegetação nativa não conservada, aplicando-se, portanto, a todos os tipos de domínios ecológico- florísticos e vegetação nativa não preservada.

Por isso mesmo, ou seja, por sua generalidade, é que se pode afirmar que a Reserva Legal obedece também ao segundo requisito necessário para que se configure uma limitação administrativa, qual seja, o da gratuidade. Assim entende Machado (2005, p. 744), ao explicar que, "considerada a generalidade da obrigação de instituir, a Reserva Legal Florestal, não cabe indenização ao proprietário por parte do Poder Público", sendo que "a obrigação de instituir e manter a Reserva Legal não grava um proprietário somente, mas todas as propriedades rurais privadas." 
É, também, a Reserva Legal Florestal, uma imposição unilateral e de ordem pública, isso porque é imposta ao proprietário por lei, qual seja, a Lei Federal 4.771 de 15 de setembro de 1.965 (Código Florestal), não podendo, portanto, ser descumprida.

Diante disso, queda claro que a Reserva Legal é uma imposição geral, imposta por Lei Federal a toda uma categoria de proprietários, devendo ser, assim, por eles respeitada, não gerando, dessa forma, qualquer tipo de indenização por parte do Poder Público, vez que não se trata de situação específica que conflita com o interesse público, sendo exigida para 0 bem-estar social, o qual, no caso, configura-se no meio ambiente ecologicamente equilibrado, bem de uso comum do povo, a que todos têm direito, e necessário à sadia qualidade de vida, consoante 0 artigo 225 da Constituição Federal.

Não se pode, pois, confundir o instituto da Reserva Legal, com a desapropriação ou servidão, já que essas geram indenização, exatamente por serem impostas apenas em situações particulares, ao passo que aquela é aplicada genericamente, como forma de alcançar-se o bem estar da coletividade, sendo por isso mesmo uma imposição gratuita.

Além disso, importante lembrar que também não ocorre com a instituição da Reserva Legal impedimento total da propriedade (desapropriação indireta), já que, além de estabelecer 0 artigo 16 do Código Florestal apenas uma porcentagem mínima do terreno rural para esse fim, ainda permite que seja tal área utilizada para fins econômicos de acordo com plano de manejo sustentável, apresentando-se, portanto, somente como um impedimento parcial dos poderes de uso, gozo e disposição do proprietário, isto é, como uma imposição "condicionadora do exercício de direitos ou de atividades particulares às exigências do bem-estar social" (M EIRELLES, 2007, p. 632).

Inegável, pois, que a Reserva Legal é uma limitação administrativa, e mais, limitação administrativa de caráter ambiental, tendo em vista o bem jurídico que se busca tutelar, ou seja, o interesse coletivo que se quer proteger com a sua instituição, que é, como já visto, a proteção do meio ambiente ecologicamente equilibrado. $E$, de acordo com tal interesse é que se provará nas linhas que seguem o fundamento, a legitimidade da imposição da Reserva Legal como limitação administrativa.

Ora, como visto, os bens jurídicos protegidos por meio de tal instituição são as "florestas e outras formas de vegetação nativa" (artigo 16 do Código Florestal), independentemente de essas estarem conservadas. De acordo com a interpretação conjunta 
do artigo 16 com 0 artigo 1ำ, caput e parágrafo $2^{\circ}$, ambos do Código Florestal, verifica-se que tais bens jurídicos protegidos são necessários "ao uso sustentável dos recursos naturais, à conservação e reabilitação dos processos ecológicos, à conservação da biodiversidade e ao abrigo e proteção de fauna e flora nativas" (artigo 1o, parágrafo 2o do Código Florestal), sendo considerados "bens de interesse comum a todos os habitantes do País" (artigo 1으, caput do Código Florestal).

Assim, tendo em vista que "o meio ambiente ecologicamente equilibrado é bem de uso comum do povo e essencial à sadia qualidade de vida" (art. 225 da CF), incumbindo-se o Poder Público de "definir, em todas as unidades da Federação, espaços territoriais e seus componentes a serem especialmente protegidos" (art. 225, parágrafo 1ํ, inciso III da CF), evidencia-se que o que se procura proteger com o instituto da Reserva Legal é o meio ambiente, figurando tal instituto, como visto, como referido espaço territorial especialmente protegido, com vistas à proteção do meio ambiente ecologicamente equilibrado, o qual, sendo bem de todos e essencial à sadia qualidade de vida, é necessário para o bem estar social.

Dessa forma, vez que o Código Florestal é Lei Ordinária Federal que condiciona o exercício dos poderes de propriedade à conservação do meio ambiente, isto é, em favor do bem comum - estabelecendo limitações para os proprietários diante de seus bens, dentre as quais a Reserva Legal - , queda claro que está materialmente recepcionado pela Constituição Federal vigente, já que, ao instituir a Reserva Legal, restringindo e condicionando o direito de propriedade, concretiza a função socioambiental dessa, preceituada nos seus artigos 50 , inciso XXIII, 170, inciso III, 186, inciso II e 225.

Nesse sentido, para a concretização da função socioambiental da propriedade, com a conseqüente preservação do meio ambiente ecologicamente equilibrado (interesse comum que se busca com a Reserva Legal) é que o parágrafo 1, inciso III do referido artigo 225 , estabelece que serão definidos espaços territoriais especialmente protegidos, vindo 0 Código Florestal instituir a Reserva Legal como um desses espaços, solidificando-se, dessa maneira, a função socioambiental da propriedade.

É, pois, assim que, instituindo a Carta Magna que a propriedade deverá atender a sua função social (artigo 5o, inciso XXIII e artigo 170, inciso III), determinando que 0 atendimento dessa pela propriedade rural se dará - em conjunto com outras medidas - com

ReVista de Direito Público, LondRina, V, 4, N. 3, P. 71-97, SEt./ DeZ. 2009. 
a preservação do meio ambiente (artigo 186, inciso II) e estabelecendo, no artigo 225, que 0 meio ambiente é bem comum, de maneira que cabem a todos a sua preservação, justifica-se a existência de espaços territoriais especialmente protegidos (artigo 225, parágrafo 1 , inciso III). E, assim, já que o dever de preservar e proteger o meio ambiente é de todos, inclusive, portanto, do proprietário, sendo que para que seja cumprida a função social da propriedade rural é necessário que se tenha em vista tal proteção (a função ambiental), é que o Código Florestal está autorizado a restringir o exercício dos direitos de propriedade do proprietário rural, obrigando-o à observação de uma porcentagem mínima em sua propriedade à ser demarcada, averbada e preservada à título de Reserva Legal.

Nesse liame, tendo em vista que uma limitação administrativa de caráter ambiental ao direito de propriedade está fundamentada na função socioambiental dessa, evidencia-se que a Reserva Legal é limitação administrativa fundamentada na função social e ambiental da propriedade. Portanto, ao mesmo tempo em que a função socioambiental legitima o instituto da Reserva Legal, também concretiza-se por meio dele.

Cumpre observar, ainda, que o Código Florestal, como Lei Federal que é, encontrase recepcionado formalmente pela Constituição Federal de 1988, de acordo com os dispositivos 23, inciso VII e 24, inciso VI e parágrafo 1ํ, vez que se trata, o Código Florestal, de um compilado de normas gerais sobre a proteção e preservação das florestas e outros tipos de vegetação, ditadas pela União no âmbito de seu poder de legislar concorrente. Nesse passo, aos Estados caberá, consoante o parágrafo 20 do artigo 24 da Constituição Federal, legislar de modo suplementar a tais normas gerais estabelecidas pela União, de maneira que não poderão editar normas menos rígidas que as estabelecidas pelo Código Florestal.

Diante disso, demonstrada ser a Reserva Legal uma limitação administrativa legitimada pela função socioambiental da propriedade, necessário ressaltar que não caberá, - por todo o já exposto anteriormente quando da limitação administrativa, em hipótese alguma, direito à indenização por parte do proprietário rural, configurando a Reserva Legal em obrigação pelo simples fato desse figurar como tal. Se couber indenização, 0 instituto não é a limitação administrativa, podendo tratar-se de desapropriação indireta ou quaisquer outros institutos, que não o que condiciona o exercício dos direitos de propriedade, genérica 
e, portanto, gratuitamente, com vistas ao atendimento do bem estar social, sendo esse, aqui, a função socioambiental da propriedade.

Portanto, quanto à gratuidade do instituto da Reserva Legal não resta dúvida e é nesse sentido que se posiciona a doutrina e a jurisprudência, como se verifica nas palavras de Édis Millaré (2007, p. 703) de acordo com o qual "o Supremo Tribunal Federal vem entendendo pelo não cabimento de indenização das áreas destinadas à constituição de Reserva Legal, salvo nas hipóteses de desapropriação do respectivo imóvel". E, ainda nesse passo, com autoridade explica José Afonso da Silva que (2004, p. 182) "a reserva legal de florestas não é servidão, mas simples restrição ao direito de propriedade, pelo quê não é indenizável."

\section{A inconstitucionalidade do Projeto de lei № 143/ 2009 que institui o pagamento por serviços ambientais do estado do Paraná e dá outras providências}

Inicialmente, cumpre observar que, segundo a Lei Florestal do Estado do Paraná (Lei Estadual no 11.054/1995), editada de acordo com o artigo 23, inciso VII, e 24, inciso VI e parágrafo 2ำ da Constituição Federal, sendo portando lei suplementar ao Código Florestal, as áreas consideradas de Reserva Legal devem representar no Estado do Paraná um mínimo de $20 \%$ da propriedade rural (artigo 7으).

Não houve, portanto, por parte da Lei Florestal Paranaense, um aumento na porcentagem da área de Reserva Legal a ser observada pelo proprietário rural, mas apenas manteve-se a exigência do mínimo já instituído em Lei Federal, o qual, vale ressaltar, não poderia ser reduzido por Lei Estadual, mas apenas aumentado, já que essa, como visto, não possui competência para editar normas menos rígidas que aquela.

Ato contínuo, o Deputado Estadual Luiz Eduardo Cheida, propôs o Projeto de Lei no $143 / 2009$, no qual pretende-se instituir, de acordo com seus artigos $1^{\circ}$ e $2^{015}$, o pagamento

15 Art. 1o Fica instituído o Pagamento por Serviços Ambientais, direcionado ao proprietário de área rural, no Estado do Paraná, que destinar parte de sua propriedade para fins de preservação e conservação da cobertura florestal, preservação de nascentes e demais recursos hídricos, que cumpra integralmente as cotas de Reserva Legal e preservação de suas áreas de preservação permanente, na forma disciplinada pela presente Lei.

Art. 20 O Pagamento por Serviços Ambientais tem como objetivo recompensar financeiramente 0 proprietário rural, em função do valor econômico dos serviços ambientais prestados por sua área destinada para cobertura florestal, nas seguintes modalidades:

IV - Manutenção, recuperação e averbação de área de Reserva Legal;

ReVISTA de Direito PúBLICO, LondRINA, V, 4, N. 3, P. 71-97, SET./ DEZ. 2009. 
ao proprietário rural paranaense por, dentre outros ali nomeados "serviços ambientais", simples cumprimento da cota integral exigida à título de Reserva Legal.

Verifica-se, portanto, que, de acordo com os mencionados dispositivos do Projeto de Lei em questão, o proprietário, ao averbar, recuperar e manter a sua propriedade, estaria realizando um serviço ambiental e nada mais, o qual, por representar gastos, teria de ser recompensado.

Isso posto, resta entender em prol de quem estaria o proprietário prestando tal serviço ambiental. E a possível resposta encontra-se na justificativa do referido Projeto de Lei, na qual o Deputado Estadual, além de atentar para fato de que a questão da obrigação da Reserva Legal está cada vez mais em destaque e suscitar que a obediência à essa restringiria 0 acesso do pequeno e médio produtor rural à terra (à ponto de impossibilitar 0 próprio sustento de sua família), menciona que, depois de estudar o assunto, constatou que os proprietários que averbam a Reserva Legal prestam serviços a toda a comunidade, e, tendo em vista a importância da preservação do meio ambiente, seria dever de todos arcar com seu custo, motivo pelo qual o proprietário deve ser financeiramente recompensado ao prestar tal serviço.

Ora, no que concerne à alegação de que seria o cumprimento da cota de Reserva Legal ônus exacerbado ao pequeno ou médio proprietário, cabe lembrar que, em relação ao primeiro, o Código Florestal já apresentou preocupação, determinando em seu artigo 16, parágrafo 3으, que o pequeno proprietário rural poderá, para o cumprimento da manutenção ou compensação da Reserva Legal em seu imóvel, "computar os plantios de árvores frutíferas ornamentais ou industriais, compostos por espécies exóticas, cultivadas em sistema intercalar ou em consórcio com espécies nativas", não se justificando, portanto, 0 seu pagamento. E, no que tange o proprietário rural médio, tampouco se justifica, visto que a Lei Florestal Paranaense apenas estabeleceu o mínimo de $20 \%$ da propriedade rural - a que era obrigada em razão de sua competência suplementar diante do Código Florestal - a ser cumprida a título de Reserva Legal, salientando-se, ainda, que essa pode ser, de acordo com 0 artigo 16, parágrafo 20 do Código Florestal, explorada economicamente segundo plano de manejo sustentável.

Seguindo-se os passos da justificativa do Projeto de Lei ㄲo 143/2009, tem-se que 0 proprietário rural presta um serviço a toda a comunidade quando averba, mantém e 
recupera a Reserva Legal, devendo ser ressarcido por realizar ato em defesa do meio ambiente, o qual seria incumbência de todos. Realmente, é inegável que tal atitude do proprietário em prol do meio ambiente beneficia toda a coletividade, exatamente por ser esse bem comum, isto é, nem público, nem privado, possuindo todos o dever de protegê-lo, conforme 0 artigo 225 da Constituição. Mas, é também justamente essa a razão pela qual 0 proprietário tem o dever de preservação e defesa do meio ambiente frente a seu imóvel, de modo que não presta qualquer tipo de serviço à comunidade quando o faz, mas pura e simplesmente cumpre seu dever, o qual Ihe é imposto pela Constituição Federal de 1988, diante da função socioambiental da propriedade ali consagrada.

Nesse sentido, tendo em vista a nova estrutura do direito de propriedade que surgiu com a Constituição Federal de 1988, indaga-se como poderia ser obrigação de toda a comunidade arcar com a preservação ambiental da propriedade de outrem, a quem lhe foi concedido o direito com o dever de cumprir sua função socioambiental.

Portanto, o meio ambiente é sim bem de todos e a todos beneficia sua preservação, mas isso não torna o proprietário que a realiza um prestador de serviços ambientais em prol da comunidade, na medida em que possui o dever constitucional de fazê-lo, sendo papel da sociedade e do Poder Público exigir tal preservação. E, tendo isso em vista, 0 artigo 225, parágrafo $1 \stackrel{0}{ }$, inciso III da Constituição Federal, incumbe o Poder Público de determinar espaços que serão especialmente protegidos, aos quais estará obrigado o particular por força da função socioambiental da propriedade.

Dessa forma, o Poder Público, na qualidade de Poder Legislativo, institui, por meio do processo legislativo - que é expressão da soberania popular, dado ainda que todo o poder emana do povo, nos termos do artigo 1ํ, parágrafo único da Constituição Federal, de forma que estaria a sociedade aqui atuando em defesa da preservação do meio ambiente, que é bem comum -, espaços especialmente protegidos, sendo a Reserva Legal, como explicado, uma espécie desses, determinada pelo Código Florestal brasileiro.

Diante disso, como restou claro, a Reserva Legal só pode configurar-se numa limitação administrativa ao direito de propriedade de caráter ambiental legitimada pela função socioambiental da propriedade, sendo, portanto, gratuita, de maneira que não poderá, em hipótese alguma, ser o proprietário indenizado, ressarcido financeiramente, ou 
seja, pago, simplesmente pelo fato de ter obedecido a tal limitação, à qual, frisa-se, está ele obrigado.

Nesse liame, verifica-se que o Projeto de Lei 143/2009, com sua respectiva justificativa, não observa, em momento algum, as normas constitucionais, ignorando 0 direito de propriedade e proteção ao meio ambiente por elas albergados. Não leva, pois, em consideração, tal Projeto de Lei, a nova estrutura do direito de propriedade que consagra a Constituição Federal de 1988, visto que prevê o atendimento das funções social e ambiental, de modo a transformar o próprio conteúdo do direto de propriedade, e autorizando ao Poder Público limitá-lo, para que sejam cumpridas referidas funções, concretizando-se, assim, a função socioambiental da propriedade, inerente ao próprio direito a essa. Evidencia-se, dessa forma, o absurdo da completa inobservância constitucional no ressarcimento do proprietário por obediência às limitações ambientais.

Como pode, então, um Projeto de Lei Estadual instituir o pagamento pela constituição da Reserva Legal, comparando-a com um serviço ambiental, como se ainda imperasse no Brasil o direito mais puro e absoluto de propriedade, e não tivesse 0 proprietário dever nenhum diante de seu imóvel?

Como se pode chegar à conclusão de que o proprietário está prestando um serviço à sociedade e não simplesmente cumprindo um dever que tem para com ela? Como, depois de 20 anos da vigência da Constituição Federal de 1988, ainda não há atenção para a importância da tutela do meio ambiente, da função ambiental dada à propriedade, em consonância com a sua função social, mudando todo o conteúdo de direito de propriedade? E como se pode, diante de todas as doutrinas referentes às limitações ao direito de propriedade, isto é, de todo o estudo sério que se faz sobre o tema, um deputado estadual, utilizando-se do senso comum, propor uma Lei para o pagamento do proprietário que cumprir a cota de Reserva Legal em sua propriedade, tendo em vista que estaria prestando um serviço à toda a sociedade, restando injusto ter de utilizar seus próprios recursos para tanto?

Torna-se difícil, ou melhor, impossível, depois de tanto estudo sobre o tema, acreditar na constitucionalidade do Projeto de Lei № 143/2009. A tutela do meio ambiente não pode ser entendida de outra forma que não a preceituada pela Constituição, por razões óbvias ali mesmo expostas, simplesmente por todos terem direito a um meio ambiente 
ecologicamente equilibrado, vez que é esse essencial à sadia qualidade de vida (artigo 225). É necessário que o proprietário entenda o dever que possui diante da sua propriedade para com o meio ambiente $e$, conseqüentemente, para com todos, o que, entretanto, não acontecerá enquanto tal dever for tratado como um "favor", levando o proprietário a crer que o direito que possui diante de seu bem ainda é o absoluto de outros tempos.

Diante do exposto, evidencia-se a inconstitucionalidade do Projeto de Lei no 143/2009 por absoluta incongruência com o contorno previsto pela Constituição Federal de 1988 para o direito de propriedade diante de sua função socioambiental, apresentando-se, portando, incompatível com seus artigos: 50, incisos XXII e XXIII, o qual encontra-se no título constitucional referente aos Direitos e Garantias Fundamentais, garantindo o direito de propriedade na medida em que esse atenda a sua função social; 186, por conseqüência, na medida em que esse determina como será realizada tal função social na propriedade rural, incluindo a função ambiental (proteção ao meio ambiente), dentre os requisitos; 225, caput e parágrafo 10 , inciso III, tendo em vista que consagra o meio ambiente ecologicamente equilibrado como bem de todos, essencial a sadia qualidade de vida, cabendo sua defesa e proteção a todos, de modo que autoriza o Poder Público a determinar espaços territoriais especialmente protegidos; e, ainda, o 170, inciso III, o qual determina como um dos princípios da ordem econômica a função social da propriedade.

Em suma, pode-se afirmar que 0 Projeto de Lei № 143/2009, ao propor 0 pagamento por Serviços Ambientais, classificando a Reserva Legal como uma espécie desses, ignora a função socioambiental da propriedade, prevista pela Constituição Federal de 1988, que altera o conteúdo do próprio direito de propriedade e legitima as limitações administrativas de caráter ambiental previstas por Lei, dentre tais, a Reserva Legal, estabelecida pela Lei Federal 4.771/1965, o Código Florestal.

Assim, diante de todo o exposto e pelos motivos aqui explicados, evidencia-se a inconstitucionalidade do Projeto de Lei № 143/2009, que institui o pagamento do proprietário pelo cumprimento da cota de Reserva Legal em sua propriedade, não devendo restar dúvida da importância que tem a preservação do meio ambiente para todos, para a presente e as futuras gerações, não podendo, nesse sentido, ser preterido em face de um direito de propriedade que já não mais existe, qual seja, o absoluto. 


\section{Conclusão}

Após entender-se 0 novo direito de propriedade albergado pela Constituição Federal de 1988, o qual, ainda que garantido como individual não é mais absoluto, tendo em vista a função socioambiental ali presente, provou-se que a Reserva Legal Florestal nada mais é que uma limitação administrativa de caráter ambiental fundamentada na função socioambiental da propriedade, não gerando, portanto, qualquer tipo de indenização ao proprietário do imóvel.

Sendo assim, caracterizando-se a Reserva Legal Florestal como tal limitação, conclui-se pela inconstitucionalidade do Projeto de Lei Estadual no 143/2009, que ao instituir o pagamento do proprietário pelo simples cumprimento da cota de Reserva Legal em sua propriedade, ignora a nova roupagem do direito de propriedade estabelecida pela Constituição Federal de 1988, devendo, a propriedade, atender às suas funções social e ambiental, que fundamentam a Reserva Legal como limitação administrativa, imposta ao proprietário sem qualquer ressarcimento financeiro, visto que é genérica, estando o proprietário a ela obrigado apenas por figurar como tal, traduzindo-se na própria efetivação da função socioambiental da propriedade.

Nesse passo, importante atentar para a necessidade de uma maior cautela no que tange a proteção ambiental face o direito de propriedade, pois sendo aquele bem de todos e essencial à qualidade de vida, em última análise, o que se procura tutelar é a segurança, a saúde e o bem estar do ser humano (SILVA, 2004, p. 81), não podendo ser desprezado diante de um direito de propriedade (o absoluto) que sequer é albergado pela Constituição vigente.

É necessário que o proprietário entenda que tem um dever para com o meio ambiente, e, por conseguinte, para com toda a sociedade. Assim, ao instituir-se o pagamento pelo cumprimento de um dever imposto ao proprietário visando a preservação do meio ambiente, essa passa a ser compreendida como uma faculdade que o proprietário teria diante de sua propriedade, isto é, passa-se a interpretar a função socioambiental da propriedade, consagrada pela Constituição Federal de 1988 como simples faculdade do proprietário diante de seu bem e não como "o dever que legitima o poder" (LEM OS, 2008, p. 75).

Tal raciocínio é deveras perigoso para o destino de toda a coletividade, pois o meio ambiente, que é bem de todos e essencial à sadia qualidade de vida da presente e futuras 
gerações, é relegado a segundo plano - desprezando-se toda evolução sofrida pela Constituição Federal de 1988 no que tange a tutela ambiental - em prol de interesses individuais, de um direito de propriedade que deveria ter sido enterrado há mais de 20 anos.

\section{Referências}

ALVARENGA, Luciano José. Revista de Direito Ambiental. In: LECEY, E.; CAPPELLI, S. (Coord.). Reserva Legal e conservação dos domínios ecológico-florísticos brasileiros: argumentos biológicos e jurídicos para uma análise crítica da jurisprudência do Tribunal de Justiça de M inas Gerais. Revista dos Tribunais, São Paulo,v. 13, n. 51, p. 166-184, 2008.

ANJOS FILHO, Robério Nunes dos. A Função Social da Propriedade na Constituição Federal de 1988. Disponível em: \ttp://www.juspodivm.com.br/i/a/\%7BA3A7E2E6-99EC-43C7-82A9-

D07E3160D9B0\%7D_roberio-a_funcao_social.pdf>. Acesso em: 22 fev. 2009.

ANTUNES, Luciana Rodrigues. A Averbação da Reserva Legal e Servidão Florestal. 2005. Disponível em: «ttp://jus2.uol.com.br/doutrina/texto.asp?id=6766>. Acesso em: $23 \mathrm{mar}$. 2009.

ANTUNES, Paulo de Bessa. Direito Ambiental. 8. ed. Rio de Janeiro: Lumen Juris, 2005.

BASTOS, Celso Ribeiro; M ARTINS, Ives Gandra. Comentários à Constituição Brasileira. 1. ed. São Paulo: Saraiva, 1988. v. 1.

BENJAM IN, Antônio Herman V. Temas de Direito Ambiental e Urbanístico. In: FIGUEIREDO, G. J. P. (Coord.). Desapropriação, Reserva Florestal Legal e Áreas de Preservação Permanente Instituto Brasileiro de Advocacia Pública, São Paulo, v. 2, n. 3, p. 63-79, 1998.

BERNARDES, Juliano Taveira. Da Função Social da Propriedade Imóvel: Estudos do Princípio Constitucional e de sua Regulamentação pelo Novo Código Civil Brasileiro, 2001. Disponível em:

বhttp://209.85.229.132/search?q=cache:UbgueRbMJD4J:jus2.uol.com.br/doutrina/texto.asp $\% 3 F i d \% 3 D 4573+$ tonstitui\%C3\%A7ao+de+1937+propriedade $\&$ hl $=e s \& c t=c \mid n k \& c d=8>$. Acesso em: 21 fev. 2009.

BONAVIDES, Paulo; ANDRADE, Paes de. História Constitucional do Brasil. 5. ed. Brasília: OAB Editora, 2004.

BRAGA, Rodrigo Bernardes. Notas sobre a Reserva Legal: uma nova abordagem, 2003.

Disponível em:

বhttp://74.125.113.132/search?q=cache:hJGg39FaFFc):jus2.uol.com.br/doutrina/texto.asp\% 3 Fid\%3D4797+reserva+legal +jurisprud\%C3\%AAncia\&cd $=1 \& h|=e s \& c t=c| n k \& g l=b r>$. Acesso em: 23 mar. 2009. 
BRASIL, Constituição, 1824. Constituição Política do Império do Brazil de 25 de março de 1824. Disponível em:

বttp://www.planalto.gov.br/ccivil_03/constituicao/constitui\%C3\%A7ao24.htm>. Acesso em: 01 mar. 2009.

. Constituição, 1891. Constituição da República dos Estados Unidos do Brasil de 24 de fevereiro de 1891. Disponível em:

«ttp://www.planalto.gov.br/ccivil_03/Constituicao/Constitui\%C3\%A7a091.htm>. Acesso em: 01 mar. 2009.

. Constituição, 1934. Constituição da República dos Estados Unidos do Brasil de 16 de julho de 1934. Disponível em:

\ttp://www.planalto.gov.br/ccivil_03/Constituicao/Constitui\%C3\%A7ao34.htm>. Acesso em: 01 mar. 2009.

. Constituição, 1937. Constituição da República dos Estados Unidos do Brasil de 10 de novembro de 1937. Disponível em:

ঝttp:// www.planalto.gov.br/CCIVIL/Constituicao/Constitui\%C3\%A7a037.htm>.Acesso em 01 mar. 2009.

. Constituição, 1946. Constituição dos Estados Unidos do Brasil de 18 de setembro de 1946. Disponível em:

বttp://www.planalto.gov.br/ccivil_03/constituicao/Constitui\%C3\%A7a046.htm>. Acesso em: 01 mar. 2009.

. Lei no 4.771, de 15 de setembro de 1965. Institui o novo Código Florestal. Disponível em: ঝttp://www.planalto.gov.br/ccivil_03/LEIS/L4771.htm>. Acesso em: 03 mar. 2009.

Disponível em:

. Constituição, 1967. Constituição da República Federativa do Brasil de 1967.

বttp://www.planalto.gov.br/ccivil_03/constituicao/Constitui\%C3\%A7a067.htm>. Acesso em: 01 mar. 2009.

. Emenda Constitucional, 1969. Emenda Constitucional no 1, de 17 de outubro de 1969. Disponível em:

«ttp://www.planalto.gov.br/ccivil_03/constituicao/Emendas/Emc_anterior1988/emc0169. htm >. Acesso em: 01 mar. 2009.

. Lei no 6.015, de 31 de dezembro de 1973. Dispõe sobre os registros públicos e dá outras providências. Disponível em: «ttp://www.planalto.gov.br/CCIVIL/LEIS/L6015.htm>. Acesso em: 20 mar. 2007.

. Constituição, 1988. Constituição da República Federativa do Brasil de 5 de outubro de 1988. Disponível em:

বttp://www.planalto.gov.br/ccivil_03/Constituicao/Constitui\%C3\%A7ao.htm>. Acesso em: 03 mar. 2009. 
Disponível em:

. Lei no 11.054, de 11 de janeiro de 1995. Dispõe sobre a Lei Florestal do Estado.

বhttp://celepar7.pr.gov.br/sia/atosnormativos/atos2/exibir_ato.asp?codAto=29>. Acesso em: 30 abr. 2009.

. Código Civil, 2002. Institui o Código Civil. Disponível em:

¿tttp://www.planalto.gov.br/CCivil_03/LEIS/2002/L10406.htm>. Acesso em: 13 mar. 2009.

. Decreto no 6.514, de 22 de julho de 2008. Dispõe sobre as infrações e sanções administrativas ao meio ambiente, estabelece o processo administrativo federal para apuração destas infrações, e dá outras providências. Disponível em:

«ttp://www.planalto.gov.br/ccivil_03/_Ato2007-2010/2008/Decreto/D6514.htm>.Acesso em: 20 mar. 2009.

. Projeto de Lei ํㅜ 143, de 07 de abril de 2009. Institui o Pagamento por Serviços Ambientais do Estado do Paraná e dá outras providências. Disponível em:

«ttp://www.cheida.com.br/projetolei.php?idprojeto=17 >. Acesso em: 30 abr. 2009.

CARVALHO, Raquel M elo Urbano de. Curso de Direito Administrativo. 1. ed. Salvador: Juspodivm, 2008.

CASSEB, Paulo Adib. Função Social da Propriedade. 2000.

CLARO, Daniel Fernandes. A função social da propriedade urbana na Constituição Federal: instrumentos coercitivos de efetivação, 2007. Disponível em:

বttp://www.fadisp.edu.br/download/5_A_Funcao_Social_da_Propriedade.pdf>. Acesso em: 20 fev. 2009.

COM PARATO, Fábio Konder. Direitos e Deveres Fundamentais em matéria de Propriedade. Disponível em: ঝttp://academico.direito-rio.fgv.br/ccmw/images/5/55/Comparato.pdf>. Acesso em: 21 fev. 2009.

DECASTRO, Rui Afonso Maciel. A Função Sócio Ambiental da Propriedade na Constituição de 1988. 2003. Disponível em: $\triangleleft t t p: / / j u s 2 . u o l . c o m . b r / d o u t r i n a / t e x t o . a s p ? i d=5765 \& p=3>$. Acesso em: 23 mar. 2009.

DI PIETRO, Maria Sylvia Zanella. Direito Administrativo. 20. ed., São Paulo: Atlas, 2007.

FERREIRA, Simone Nunes. Direito de Propriedade: nas Constituições Brasileiras e do M ercosul. Disponível em:

«ttp://www.planalto.gov.br/ccivil_03/revista/Rev_83/artigos/PDF/Simone_rev83.pdf>. Acesso em: 22 fev. 2009.

FIGUEIREDO, Guilherme José Purvin de. A Propriedade no Direito Ambiental. 3. ed. São Paulo: Revista dos Tribunais, 2008. 
FIORILLO, Celso Antonio Pacheco. Curso de Direito Ambiental Brasileiro. 10. ed. São Paulo: Saraiva, 2009.

FIORILLO, Celso Antonio Pacheco. Direito Ambiental Tributário. 2. ed. São Paulo: Saraiva, 2009.

GOM ES, Daniela Vasconcellos. A Noção de Propriedade no Direito Civil Contemporâneo, 2006. Disponível em: ঝttp://www.ripj.com/art_jcos/art_jcos/num18/Art.18_PDF/186Revista\%20Internauta\%20de\%20Pr\%C3\%Alctica\%20Jur\%C3\%ADdica\%20\%20A\%20no\%C3\%A7\%C3\%A30\%20de\%20propriedade\%20no\%20direito\%20civil\%20contem por\%C3\%A2neo.pdf>. Acesso em: 20 fev. 2009.

GRANZIERA, M.; AM ORIM , L.; COSTA, L. M eio Ambiente e Acesso à Justiça: Flora, Reserva Legal e APP. In: BENJAM IN, A.; LECEY, E.; CAPELLI, S. (Coord.). A Reforma do Código Florestal: um estudo acerca da Incidência da Função Socio-Ambiental e das Limitações Administrativas ao Imóvel Rural. São Paulo: Imprensa Oficial do Estado de São Paulo, 2007. p. 503-516. v. 2.

GRISARD FILHO, Waldyr. Função Social da Propriedade (do direito de propriedade ao direito à propriedade). In: RAM OS, C. L. S. (Coord.). Direito Civil Constitucional: Situações Patrimoniais. 1. ed. Curitiba: Juruá, 2007. p.233-252.

LEM OS, Patrícia Faga Iglecias. M eio Ambiente e Responsabilidade Civil do Proprietário: Análise do Nexo Causal. 1. ed. São Paulo: Revista dos Tribunais, 2008.

M ACHADO, Paulo Affonso Leme. Direito Ambiental Brasileiro. 13. ed. São Paulo: Malheiros, 2005.

M AGALHÃES, Vladmir Garcia. A Reserva Legal na Propriedade Agrária. 2001.

M EIRELLES, Hely Lopes. Direito Administrativo Brasileiro. 33. ed. São Paulo: Malheiros, 2007.

M ILARÉ, Édis. Direito do Ambiente: A Gestão Ambiental em Foco. 5. ed. São Paulo: Revista dos Tribunais, 2007.

M OESH, Frederico Fernandes. O Princípio da Função Social da Propriedade e sua Eficácia, 2005. Disponível em: «ttp://jus2.uol.com.br/doutrina/texto.asp?id=7645>. Acesso em: 22 fev. 2009.

M ONTEIRO, Washington de Barros. Curso de Direito Civil: direito das coisas. 37. ed. São Paulo: Saraiva, 2003. v. 3.

M ORAES, Alexandre de. Direito Constitucional. 18. ed. São Paulo: Atlas, 2005.

SILVA, José Afonso da. Direito Ambiental Constitucional. 5. ed. São Paulo: Malheiros, 2004. 
. Curso de Direito Constitucional Positivo. 24. ed. São Paulo: M alheiros, 2005.

. Curso de Direito Constitucional Positivo. 22. ed. São Paulo: Malheiros, 2003.

TARTUCE, Flávio. Introdução Crítica ao Código Civil. In: BARROSO, L. A. (Coord.). Questões polêmicas quanto ao direito das coisas no novo Código Civil. Visão crítica sobre a nova codificação. 1. ed. Rio de Janeiro: Editora Forense, 2006.

TAVARES, André Ramos. Curso de Direito Constitucional. 5. ed. São Paulo: Saraiva, 2007.

VENOSA, Sílvio de Salvo. Direito Civil : direitos reais. 6. ed. São Paulo: Atlas, 2006. v. 4.

VIANA, Marco Aurélio S., Comentários ao Novo Código Civil: dos direitos reais. 1. ed. Rio de Janeiro: Forense, 2003. v. 16.

VIANNA, José Ricardo Alvarez. Responsabilidade Civil por Danos ao M eio Ambiente. 22. ed., Curitiba: Juruá, 2004. 